\title{
Analysis of Aggression Tendencies Elite Athletes Karate in Turkey
}

\section{Abdullah Arisoy ${ }^{1 *}$, Mert İmran Koç ${ }^{2}$, Alperen Akpinar ${ }^{3}$, Dilara Özsaraç4}

${ }^{1 *}$ Faculty of Sport Sciences, Süleyman Demirel University, Isparta, Turkey

${ }^{23}$ Sports Management Department, Faculty of Sport Sciences, Süleyman Demirel

University, Isparta, Turkey

${ }^{4}$ Institute of Health Sciences, Erciyes University, Kayseri, Turkey

\begin{abstract}
Article History:
Received: 18 March 2021

Accepted: 20 April 2021

Published: 26 April 2021
\end{abstract}

Keywords:

Karate, Athlete; Aggression

\begin{abstract}
The aim of this study is to examine the aggression tendencies of elite karate athletes according to some variables. The sample group of the study was composed of 160 karate athletes selected voluntarily among 400 karate athletes who reached the level of nationality. In the study, the participants were asked to fill in the socio-demographic information form and the Buss and Perry Aggression scale. The analysis of the data was done in computer environment. The arithmetic, mean and standard deviation of the scores the participants got from the scale are presented as $\mathrm{x} \pm \mathrm{sd}$. For paired comparisons, t-test for independent variables and anova were used for more than two comparisons. LSD test was applied to reveal a significant difference in more than two comparisons. The level of significance was accepted as $p<0.05$. As a result, karateists aggressive tendencies are above average, $\mathrm{A}$ statistically significant difference was found among the subtitles in physical aggression, physical aggression and aggression total scores according to nationality of according to gender. It is thought that this situation is caused by the physical and psychological influences of elite athletes are exposed to before, during or after the competition.
\end{abstract}

\section{How To Cite:}

Arisoy, A, Koç, M. I., Akpinar, A, \& Özsaraç, D. (2021). Analysis of Elite Karate Athletes Aggression Tendencies According to Some Variables. Indonesian Journal of Sport Management, 1(1), 1-10. https://doi.org/10.31949/ijsm.v1i1.948

Corresponding author: Abdullah Arisoy, Faculty of Sport Sciences, Süleyman Demirel University, Isparta, Turkey

Email: abdullaharisoy@hotmail.com 


\section{INTRODUCTION}

The concept of sport first evokes terms such as comfort, struggle, health, development and entertainment in the human mind. Sport contains many feelings and thoughts besides just these terms. People are in an effort to explore beyond their own limits and prove themselves to the community through sports (Görmez, 2017). However, with the help of the competitive environment of sports and the developing science of sports, performance in many sports branches has increased.

Performance is the meaningful and successful application of an individual's ability and capacity while performing a task (Başer, 1996). Sportive performance, on the other hand, is defined as all efforts to achieve success in the performance of an athletic task (Kurtoğlu, 2004). Performance is not only a physical feature, but also a psychological process. Psychological factors that affect performance consist of characteristics such as motivation, anxiety, self-confidence, personality, attention, concentration, assertiveness, determination, persistence, and self-control (Arno, 1984).

As a training process aimed at optimizing the physical and mental strength, technical and tactical capacities of athletes against physical and psychological loads (Türkay \& Gökbel, 2020), their training, psychological preparation for competitions is one of the most important factors for success in sports (Karabulut, 2010). In the studies conducted, reasons such as excessive tension, insufficient concentration, lack of motivation, negative thoughts, self-confidence and inability to cope with stress negatively affect performance (Ekstrand \& Hodson, 2003). This situation can be seen in sportive activities, such as aggression and violence seen in all aspects of our lives. Kuru (2000) defines aggression as a tendency to show aggressive behavior and has a relatively continuous feature. According to another definition, aggression is defined as "behaviors that aim to harm a living thing and that the target individual wants to escape" (Richardson, 1994).

In the literature review made by the researcher; In addition to team sports such as football, volleyball, futsal and basketball (Afyon \& Metin, 2015; Aksu \& Tutar, 2020; Özdemir \& Abakay, 2017; Erdoğdu et al, 2018; Aktaş et al, 2004), taekwondo (Kahveci et al, 2020), wrestling (Shokoufeh \& Türkmen, 2019; Ersoy et al, 2012) muay thai (Eraslan et al, 2019) and studies examining the aggression levels of athletes engaged in some defense sports (Güvendi \& Pehlivan, 2020) were discussed. However, it has been observed that studies on karate athletes are limited. Therefore, the aim of this study is to examine the aggression tendencies of elite karate athletes in terms of some variables.

\section{METHOD}

In the research, a method for descriptive scanning aiming to reveal the current situation was used. In descriptive methods, the event, individual or object subject to research is tried to be defined in its own conditions and as it is. (Karasar, 2004). The sample group of the study was composed of 160 karate athletes selected voluntarily among 400 karate athletes who reached the level of nationality. In the study, they were asked to fill in the socio-demographic information form and the Buss and Perry Aggression scale. 
A 4-question socio-demographic information form including gender, age, education and nationality of the volunteer students participating in the study was created. Socio-demographic information of karate athletes is presented in Table 1.

Table 1. Descriptive Statistics of the Participants

\begin{tabular}{cccc}
\hline Variables & Groups & $\mathbf{N}$ & $\mathbf{\%}$ \\
\hline \multirow{3}{*}{ Gender } & Male & 95 & $59,4 \%$ \\
& Female & 65 & $40,6 \%$ \\
& Total & 160 & $100 \%$ \\
& $18-20$ & 34 & $21,3 \%$ \\
Age & $21-23$ & 86 & $53,8 \%$ \\
& $24+$ & 40 & $25,0 \%$ \\
& Total & 160 & $100 \%$ \\
Education Status & Pre- & 24 & $15 \%$ \\
& License & & \\
& License & 120 & $75 \%$ \\
& Graduate & 16 & $10 \%$ \\
Being National Athlete & Total & 160 & $100 \%$ \\
& Yes & 85 & $53,1 \%$ \\
& No & 75 & $46,9 \%$ \\
& Total & 160 & $100 \%$ \\
\hline
\end{tabular}

When Table 1 is examined, $59.4 \%$ of the athletes are male, $40.6 \%$ are female, according to age groups, $21.3 \%$ are $18-20,53.8 \%$ are $21-23,25.0 \%$ are $24+$. According to educational status it was determined that $15.0 \%$ was pre-license, $75.0 \%$ was license, $10.0 \%$ was graduate and above, and according to national status, $53.1 \%$ was national athlete and $46.9 \%$ was not national athlete.

The scale, which aims to determine aggression with its different dimensions, was developed by Buss and Perry (1992) and adapted to Turkish by Mardan (2013). The scale is 5-point Likert type and consists of 29 items. The scale has 4 dimensions: oral aggression, physical aggression, anger and hostility. For the Turkish form of the internal consistency coefficients of the scale items; It was 0.78 for the physical aggression subscale, 0.71 for the hostility subscale, 0.71 for the anger subscale, 0.48 for the oral aggression subscale, and 0.85 for the whole scale. The existence of studies evaluating the Buss and Perry scale on the total score, as well as evaluating the subtitles, were also reported (Mardan, 2013).

\section{RESULT AND DISCUSSION}

\section{Statistical Analysis}

The analysis of the data was done in computer environment. Kolmogorov-Smirnov test was applied for the normality distribution of the scores obtained from the scale and the test results are presented in Table 2.

When Table 2 is examined; In the distribution of the scores of the scale, it was found that aggression total and aggression subtitles were normal for hostility ( $\mathrm{p}>$ $.005)$, and physical aggression, anger and oral aggression $(p<0,5)$ from the aggression scale subtitles were not found to be normal. It was found that the skewness and kurtosis values were in the range of \pm 1 . When the literature is 
examined; It was seen that these values being in the \pm 1 interval was interpreted as not excessive deviations from normality (Büyüköztürk, 2007).

Table 2. Skewness-Kurtosis and Kolmogorov-Smirnov Test Significance Level Results of the Scale Scores of the Participants

\begin{tabular}{lcccc}
\hline Buss and Perry Aggression & $\mathbf{N}$ & Skewness & Kurtosis & $\mathbf{p}$ \\
\hline Physical Aggression & 160 & .238 & -.488 & .000 \\
Anger & 160 & -.002 & -.361 & .018 \\
Hostility & 160 & -.079 & -.397 & .200 \\
Oral aggression & 160 & .079 & .081 & .006 \\
Aggression Total & 160 & .014 & .188 & .200 \\
\hline
\end{tabular}

Based on this information, it has been accepted that the data show a normal distribution. In the study, the arithmetic means and standard deviation of the scores obtained by the participants from the scale are presented as $\mathrm{x} \pm \mathrm{sd}$. In paired comparisons, t-test for independent variables and anova were used for more than two comparisons. LSD test was applied to reveal a significant difference in more than two comparisons. The level of significance was accepted as $\mathrm{p}<0.05$.

\section{Findings}

Table 3: Descriptive Statistics Scores of the Participants Received from the Scales

\begin{tabular}{lcccc} 
Buss and Perry Aggression & N & Min & Max & X \pm Sd \\
\hline Physical Aggression & 160 & 13.00 & 45.00 & $31.125 \pm 6.415$ \\
Anger & 160 & 11.00 & 33.00 & $22.906 \pm 4.447$ \\
Hostility & 160 & 12.00 & 37.00 & $25.988 \pm 5.258$ \\
Oral aggression & 160 & 5.00 & 25.00 & $15.513 \pm 3.338$ \\
Aggression Total & 160 & 41.00 & 133.00 & $95.531 \pm 15.859$ \\
\hline
\end{tabular}

It was determined that the aggression level average of 160 karate athletes participating in the study was $95.53 \pm 15.85$. When the sub-dimensions of the aggression scale are examined; It was determined that physical aggression was $31.12 \pm 6.41$, anger was $22.90 \pm 4.44$, hostility was $25.98 \pm 5.25$, oral aggression was $15.51 \pm 3.33$ (Table 3).

Table 4: Aggression Scale Scores by Age of Athletes

\begin{tabular}{|c|c|c|c|c|c|c|}
\hline & Age & $\mathbf{N}$ & $\mathrm{X} \pm \mathrm{Sd}$ & f & $\mathbf{p}$ & LSD \\
\hline & $18-20$ & 34 & $31.76 \pm 6.52$ & & & \\
\hline \multirow{2}{*}{ Physical Aggression } & $21-23$ & 86 & $30.63 \pm 6.38$ & .534 & .588 & - \\
\hline & $24+$ & 40 & $31.62 \pm 6.45$ & & & \\
\hline \multirow{3}{*}{ Anger } & $18-20$ & 34 & $22.17 \pm 4.62$ & & & \\
\hline & $21-23$ & 86 & $22.72 \pm 4.24$ & 1.594 & .206 & - \\
\hline & $24+$ & 40 & $23.92 \pm 4.64$ & & & \\
\hline \multirow{3}{*}{ Hostility } & $18-20$ & 34 & $24.88 \pm 6.00$ & & & \\
\hline & $21-23$ & 86 & $25.81 \pm 4.66$ & 2.072 & .129 & - \\
\hline & $24+$ & 40 & $27.30 \pm 5.63$ & & & \\
\hline \multirow{3}{*}{ Oral Aggression } & $18-20$ & 34 & $14.61 \pm 3.50$ & & & \\
\hline & $21-23$ & 86 & $15.61 \pm 3.33$ & 1.799 & .169 & - \\
\hline & $24+$ & 40 & $16.05 \pm 3.12$ & & & \\
\hline \multirow{3}{*}{ Aggression Total } & $18-20$ & 34 & $93.44 \pm 17.14$ & & & \\
\hline & $21-23$ & 86 & $94.79 \pm 15.29$ & 1.296 & .276 & - \\
\hline & $24+$ & 40 & $98.90 \pm 15.82$ & & & \\
\hline
\end{tabular}


It was determined that there was no significant difference between the aggression total scores and aggression sub-dimensions of the athletes and their ages ( $p>0.05$ ). However, considering the average scores, it was observed that athletes aged 24 and over were more aggressive than others in the sub-dimensions of aggression total score, anger, hostility, and oral aggression. In the physical aggression sub-dimension of the scale; It has been observed that athletes between the ages of 18-20 are more aggressive than others (Table 4).

In comparison of the aggression levels of karate athletes according to gender variable; After the t test for anger comparison, no significant difference was found between the aggression scores of females $(\bar{x}=94.14)$ and male $(\bar{x}=97.55)$ athletes. When sub-dimensions of the aggression scale were compared, it was found that physical aggression levels of male and female athletes were different from each other $(\mathrm{t}=2.522)$. Accordingly, the physical aggression levels of male athletes $(\overline{\mathrm{x}}=$ $32.64)$ are higher than the physical aggression levels of female athletes $(\bar{x}=30.08)$. When the other sub-dimensions were examined, no significant difference was found between male and female athletes (Table 5).

Table 5: Aggression Scale Scores of Athletes According to Gender Variable

\begin{tabular}{|c|c|c|c|c|c|}
\hline & Gender & $\mathrm{N}$ & $\mathrm{X} \pm \mathrm{Sd}$ & $\mathrm{t}$ & $\mathrm{p}$ \\
\hline \multirow{2}{*}{ Physical Aggression } & Female & 95 & $30.08 \pm 5.97$ & \multirow{2}{*}{-2.522} & \multirow{2}{*}{$.013^{*}$} \\
\hline & Male & 65 & $32.64 \pm 6.76$ & & \\
\hline \multirow{2}{*}{ Anger } & Female & 95 & $22.81 \pm 4.55$ & \multirow{2}{*}{-.328} & \multirow{2}{*}{.743} \\
\hline & Male & 65 & $23.04 \pm 4.31$ & & \\
\hline \multirow[b]{2}{*}{ Hostility } & Female & 95 & $25.75 \pm 5.20$ & \multirow[b]{2}{*}{-.667} & \multirow[b]{2}{*}{.506} \\
\hline & Male & 65 & $26.32 \pm 5.35$ & & \\
\hline \multirow{2}{*}{ Oral aggression } & Female & 95 & $15.49 \pm 3.50$ & \multirow{2}{*}{-.081} & \multirow{2}{*}{.935} \\
\hline & Male & 65 & $15.53 \pm 3.11$ & & \\
\hline \multirow{2}{*}{ Aggression Total } & Female & 95 & $94.14 \pm 15.58$ & \multirow{2}{*}{-1.338} & \multirow{2}{*}{.183} \\
\hline & Male & 65 & $97.55 \pm 16.16$ & & \\
\hline
\end{tabular}

It was determined that there was no significant difference between the aggression total scores and aggression sub-dimensions of the athletes and their education level ( $p>0.05)$. However, considering the average scores, it was observed that graduate students were more aggressive than others in the sub-dimensions of aggression total score, oral aggression, and anger. In the hostility subscale and physical aggression score of the scale; It has been observed that athletes with associate degree education are more aggressive than others (Table 6).

Table 6: Aggression Scale Scores According to the Educational Background of the Athletes

\begin{tabular}{|c|c|c|c|c|c|c|}
\hline & Education & $\mathbf{N}$ & $\mathrm{X} \pm \mathrm{Sd}$ & f & $\mathbf{p}$ & LSD \\
\hline \multirow{3}{*}{ Physical Aggression } & Pre-licence & 24 & $31.83 \pm 7.08$ & \multirow{3}{*}{.192} & \multirow{3}{*}{.826} & \multirow{3}{*}{-} \\
\hline & Licence & 120 & $30.95 \pm 6.05$ & & & \\
\hline & Graduate & 16 & $31.31 \pm 8.20$ & & & \\
\hline \multirow{3}{*}{ Anger } & Pre-licence & 24 & $22.58 \pm 4.58$ & \multirow{3}{*}{.111} & \multirow{3}{*}{.895} & \multirow{3}{*}{-} \\
\hline & Licence & 120 & $22.92 \pm 4.29$ & & & \\
\hline & Graduate & 16 & $23.25 \pm 5.55$ & & & \\
\hline \multirow{3}{*}{ Hostility } & Pre-licence & 24 & $26.29 \pm 5.64$ & \multirow{3}{*}{.047} & \multirow{3}{*}{.954} & \multirow{3}{*}{-} \\
\hline & Licence & 120 & $25.93 \pm 4.97$ & & & \\
\hline & Graduate & 16 & $25.93 \pm 6.91$ & & & \\
\hline \multirow{2}{*}{ Oral aggression } & Pre-licence & 24 & $15.20 \pm 3.86$ & \multirow{2}{*}{.193} & \multirow{2}{*}{.825} & \multirow[b]{2}{*}{ - } \\
\hline & Licence & 120 & $15.52 \pm 3.12$ & & & \\
\hline
\end{tabular}




\begin{tabular}{lcccccc} 
& Graduate & 16 & $15.87 \pm 4.19$ & & & \\
& Pre-licence & 24 & $95.91 \pm 15.72$ & & & \\
Aggression Total & Licence & 120 & $95.34 \pm 15.03$ & .038 & .963 & - \\
& Graduate & 16 & $96.37 \pm 22.20$ & & & \\
\hline
\end{tabular}

A significant difference was found between the aggression scores of national and non-national athletes $(\mathrm{t}=2.506)$ after the $\mathrm{t}$ test performed to compare the aggression scale scores of national and non-national athletes. Accordingly, the aggression scores of national athletes $(\overline{\mathrm{x}}=98.43)$ are higher than the aggression scores of non-national athletes $(\overline{\mathrm{x}}=92.24)$. When the sub-dimensions of the aggression scale of national and non-national athletes were compared, only physical aggression scores were found to be different from each other $(t=2.625)$. Accordingly, the physical aggression scores of national athletes $(\overline{\mathrm{x}}=32.35)$ are higher than the physical aggression levels of non-national athletes $(\bar{x}=29.73)$ (Table 7).

Table 7: Aggression Scale Scores According to the National Status of Athletes

\begin{tabular}{cccccc}
\hline & National status & $\mathrm{N}$ & $\mathrm{X} \pm \mathrm{Sd}$ & $\mathrm{T}$ & $\mathrm{p}$ \\
\hline \multirow{2}{*}{ Physical Aggression } & Yes & 85 & $32.35 \pm 6.37$ & \multirow{2}{*}{2.625} & $.010^{*}$ \\
& No & 75 & $29.73 \pm 6.21$ & & \\
Anger & Yes & 85 & $23.48 \pm 4.81$ & \multirow{2}{*}{1.756} & .081 \\
& No & 75 & $22.25 \pm 3.91$ & & \\
Hostility & Yes & 85 & $26.61 \pm 5.62$ & \multirow{2}{*}{1.607} & .110 \\
& No & 75 & $25.28 \pm 4.75$ & & \\
Oral aggression & Yes & 85 & $15.98 \pm 3.60$ & \multirow{2}{*}{1.905} & .055 \\
\multirow{2}{*}{ Aggression Total } & No & 75 & $14.97 \pm 2.94$ & & \multirow{2}{*}{. } \\
& Yes & 85 & $98.43 \pm 17.34$ & 2.506 & $.013^{*}$ \\
\hline
\end{tabular}

In this study, it is aimed to examine the aggression levels of elite karate athletes according to some variables. When Table 3 was examined, it was found that the sub-dimensions of aggression and total score averages of the athletes participating in the study were high. When the literature is examined, in the studies about the aggression levels of the athletes; Tutkun et al. (2010) found high aggression mean scores of athletes who do individual sports. Yamak et al. (2019) found that the aggression levels of the students at sports high schools and faculties of sports sciences were moderate. In another study, Güner (2006) found that the aggression level average of athletes engaged in team sports and individual sports was medium in team sports, while it was high in individuals engaged in sports. Considering that the total score that can be obtained from the aggression scale will also vary according to the desire to achieve, win, or victory, it is thought that the high level of aggression of elite karateers is due to the direct effect of individual athletes' performance on their own achievements.

In Table 4, when the aggression levels of karate athletes were compared in terms of their ages, no significant difference was found. In some studies, it was seen that there were studies that did not find a significant difference, like our study (Demirci et al. 2020; Kahveci et al. 2020; Filiz, 2009). However, as in our study, according to average scores, some studies show that aggression increases in children, adolescents, adolescents, and adults as age increases (Çetinkaya et al. 2010). Alp and Ergül (2018) in their research; found that physical activity and sports 
activities have a positive effect on the decrease in the behavior of adolescents with a tendency to violence. Especially, they suggested that adolescents should be encouraged to participate in physical activity and sports activities.

In our study, when the total aggression scores of Karate athletes were examined by gender, no significant difference was found (Table 5). When the literature was examined, Kahveci et al. (2020) reported that there was no difference between the aggression scores of the athletes according to gender in their study to determine the aggression and happiness levels of licensed taekwondo players. Another study was conducted by Demirci et al. (2020) found that there is no difference in aggression levels of karate athletes in the 17-19 age group, which supports our study. Considering that doing sports has a preventive effect on displaying aggressive behaviors (Baltaş, 2008); It has been concluded that the athletes who are interested in the karate branch do not make a difference in terms of gender because of regular sports. In terms of gender variable, a significant difference was found in physical aggression from sub-dimensions of the aggression scale, and no difference was found in other sub-dimensions. Looking at the literature; There are studies supporting our study in which physical aggression scores of males are higher than females in physical aggression sub-dimensions (Donat-Bacıoglu and Özdemir, 2012; Giles and Heyman, 2005). In our study, although there was no statistically significant difference in anger, hostility, and oral aggression sub-dimensions, when the mean scores were considered, the ratio of females to males was higher. It is thought that the reason for this may be that female athletes express their anger more orally and males prefer to use more physical means to express their anger.

In Table 6, when the level of aggression of karate athletes was compared in terms of their education, no significant difference was found. However, when the average scores were examined, it was seen that the athletes with associate degree education were higher in the physical aggression and hostility sub-dimension than the others, and the anger and oral aggression sub-dimensions of those with graduate education were higher than the others. When the literature was examined, Topuz (2008) found in his study to examine the aggression levels of amateur football players, that the mean scores of the players who were primary, high school and university graduates in aggression sub-dimensions and total did not differ significantly. In another study by Dervent (2007), it was found that high school students who play sports and play football have a high average score of general aggression levels. According to this result, we can say that the different educational levels of karateists have no effect on their level of aggression.

When Table 7 is examined, a significant difference was found when the aggression total scores of the karate athletes in our study were examined according to their nationality status. Again, a significant difference was found in physical aggression, which is one of the sub-dimensions of the aggression scale, in terms of the national status variable, and no statistically significant difference was found in the other sub-dimensions. In the literature review conducted by the researcher, there was no study examining aggression levels in individual and team sports according to the variable of being national. Alp et al. (2014) defended the necessity of aggression in competitions where sportive success is desired, and even the necessity of aggression for sportive success, and they suggested that sportive 
activities do not matter the winner and the loser, and that they should have a physical education character in game form.

\section{CONCLUSION}

As a result, a statistically significant difference was found in the aggression tendencies of karateists, which are above average, in the subtitles of aggression by gender, physical aggression, physical aggression and aggression according to nationality. This situation is thought to be caused by the physical and psychological pressures elite athletes are exposed to before or after the competition. Studies can be conducted to examine the aggression levels of karate athletes on a larger scale.

Karate athletes can be trained on aggression tendencies, and studies can be conducted to examine the changes in their aggression levels. Studies can be conducted to compare the aggression levels of karate athletes with the aggression levels of athletes engaged in other defense sports such as Taekwondo, Wushu, Muay Thai. Studies can be conducted to examine the aggression levels of athletes engaged in individual and team sports. Studies can be conducted to examine the aggression levels of private athletes engaged in individual and team sports.

\section{ACKNOWLEDGEMENT}

I would like to thank all karate athletes who have been willing to help complete this research.

\section{REFERENCES}

Afyon, Y., \& Metin, S. (2015). Muğla Süper Amatör Ligindeki Futbolcuların Saldırganlık Düzeylerinin İncelenmesi. Spor ve Performans Araştırmaları Dergisi, 6(1), 5-11.

Aktaş, Z., Çobanoğlu, G., \& Yazıcılar, İ. (2004). Profesyonel Erkek Basketbolcuların Saldırganlık Düzeyleri ile Maç Başarıları Arasındaki İlişkinin Araştırılması. Spormetre Beden Eğitimi ve Spor Bilimleri Dergisi, 2(3), 127-134.

Alp, H., Ergül, O.K. (2018). Şiddet Eğilimli Ergenlerin Saldırgan Davranışlarına Fiziksel Aktivite ve Sportif Oyunların Etkisi. Akademik Bakış, 66, 1-11.

Alp, M., Eraslan, M, Atay, E, Özmutlu, İ. (2014). Düzenli Spor Yapan ve Yapmayan Çocukların Sosyo-Demografik Özelliklerine Göre Saldırganlık Düzeylerinin İncelenmesi. e-Kafkas Journal of Educational Research, 1(1)

Aksu A \& Tutar, Ö. F. (2020). Elazı̆ 1. Amatör Küme Futbolcularının Saldırganlık Düzeylerinin İncelenmesi.Kesit Akademi Dergisi, (23), 341-351. https://doi.org/10.29228/kesit.42886

Baltaş, A., Baltaş, Z. (2008). Stres ve Başa Çıkma Yolları (24. Basım). İstanbul: Remzi Kitabevi.

Baron, R. A. \& Richardson, D. R. (1994). Human Aggression. Second Edition. New York: Plenum Press.

Başer E. (1996). Futbolda Psikoloji ve Başarı, Sporsal Kuram Dizisi-4. (2. Baskı), Bağırgan Yayınevi, Ankara, 91-93

Bayraktar B, Kurtoglu M. (2004). Sporda performans ve performans artırma yöntemleri, in: Atasü T, Yücesir İ (eds), Doping ve futbolda performans artırma yöntemleri, İstanbul, 269-296. 
Buss, A. H., \& Perry, M. (1992). The Aggression Questionnaire. Journal of Personality and Social Psychology, 63(3), 452-459. https://doi.org/10.1037/0022-3514.63.3.452

Büyüköztürk, Ș. (2007). Sosyal Bilimler Için Veri Analizi El Kitabı. (7. Baskı), Pegem Akademi Yayıncllık, 40.

Çetinkaya Yıldız, E. ve Hatipoğlu Sümer, Z. (2010). Saldırgan davranışlarını yordamada çevresel risk, çevresel güvenlik ve okul iklimi algısı. Türk Psikolojik Danışma ve Rehberlik Dergisi, 4(34), 161-171.

Çobanoğlu Güner, B. (2006). Takım Sporları ve Bireysel Sporlar Yapan Sporcuların Saldırganlık Düzeylerinin İncelenmesi, Ondokuz Mayıs Üniversitesi Sağlık Bilimleri Enstitüsü Yüksek Lisans Tezi, Samsun

Demirci, E., Karagün E., Alp A.F. (2020) 17-19 Yaș Grubu Karate Sporcularının Saldırganlık Düzeylerinin İncelenmesi. 18. Uluslararası Spor Bilimleri Kongresi 07-09 Kasım 2020. SB447

Demirtaş Mardan, H. A. (2013). Buss-Perry Saldırganlık Ölçeği'nin Türkçe Formunun Geçerlik ve Güvenirlik Çalışması. Türk Psikiyatri Dergisi, 24(2), 124-129

Dervent F. (2007). Lise Öğrencilerinin Saldırganlı Düzeyleri ve Sportif Aktivitelere Katılımla İlişkisi, Gazi Üniversitesi Eğitim Bilimleri Enstitüsü Beden Eğitimi ve Spor Öğretmenliği Ana Bilim Dalı Yüksek Lisans Tezi, Ankara

Donat-Bacıoğlu, S. ve Özdemir, Y. (2012). İlköğretim öğrencilerinin saldırgan davranışları ile yaş, cinsiyet, başarı durumu ve öfke arasındaki ilişkiler. Eğitim Bilimleri Araştırmaları Dergisi-Journal of Educational Sciences Research, 2(2), 169-187.

Ekstrand J, Karlsson J, Hodson A. (2003). Football Medicine. Taylor and Francis Group: 39121

Eraslan, M., Karafil, A. Y., Akgül, M. H., \& Korkmaz, S. (2019). Üniversiteler Arası Spor Müsabakalarına Katılan Muay Thai Sporcularının Șiddet Eğilimlerinin Değerlendirilmesi. Mehmet Akif Ersoy Üniversitesi Sosyal Bilimler Enstitüsü Dergisi, 9(22), 404-412. https://doi.org/10.20875/makusobed.359528

Erdoğdu, M., Koçyiğit, M., Kayışoğlu, N. B., \& Yılmaz, B. (2018). Futbol ve Futsal Branşlarında Spor Yapan Genç Kadınların Saldırganlık Yaklaşımları. Uluslararası Kültürel ve Sosyal Araştırmalar Dergisi (UKSAD), 4(Special Issue 3), 1-14

Ersoy, A., Tazegül, Ü., \& Sancaklı, H. (2012). Güreşçilerin saldırganlık düzeylerinin sosyo demografik açıdan incelenmesi (Ankara örneği). Uluslararası İnsan Bilimleri Dergisi, 9(1), 385-397.

Filiz A. (2009). Farklı Lise Türlerindeki Öğrencilerin Empatik Eğilimleri ve Saldırganlık Düzeylerinin İncelenmesi (Yayımlanmamış yüksek lisans tezi). Yeditepe Üniversitesi, İstanbul.

Giles, J. W. \& Heyman, G. D. (2005). Young children's beliefs about the relationship between gender and aggressive behaviour. Child Development, 76, 107-121.

Görmez, A. (2017). Ankara İli Merkez İlçelerinde Öğrenim Gören Ortaöğretim Öğrencilerinin Spora Yönelmelerini Etkileyen Etmenlerin Chaid Analizi ile İncelenmesi, Ankara Üniversitesi Sağlık Bilimleri Enstitüsü Yüksek Lisans Tezi, Ankara.

Güvendi, B., \& Pehlivan, M. Y. (2020). Dövüş Sporcularının Kendi Kendilerine Konuşmaları ile Saldırganlık ve Öfke Davranışlarının İncelenmesi. Beden Eğitimi ve Spor Bilimleri Dergisi, 14(2), 168-176. 
Kahveci, İ., Karagün, E., \& Kahveci, M. S. (2020) Kocaeli İlinde Çalışan Lisanslı Taekwondocuların Saldırganlık ve Mutluluk Düzeylerinin Belirlenmesi. OPUS Uluslararası Toplum Araştırmaları Dergisi,16(29 Ekim Özel Sayısı), 1-1. https://doi.org/10.26466/opus.728250

Karabulut, O., Atasoy, M., Kaya K., Karabulut, A. (2013). 13-15 yaş arası erkek futbolcuların durumluk ve sürekli kaygı düzeylerinin farklı değiş̧kenler bakımından incelenmesi. Ahi Evran Üniversitesi Kırşehir Eğitim Fakültesi Dergisi, 14(1), 243-253

Karasar, N. (2004). Bilimsel araștırma yöntemi. Nobel yayıncılık, Ankara, 52.

Kuru, E. (2000). Sporda Psikoloji, Gazi Üniversitesi İletişim Basımevi, Ankara.

Özdemir, N., \& Abakay, U. (2017). Kadın voleybol ve futbolcularda iletişim becerileri ve saldırganlık düzeylerinin incelenmesi. Gaziantep Üniversitesi Spor Bilimleri Dergisi, 2(1), 41-52

Shokoufeh, S., \& Türkmen, M. (2019). Türkiye'de Elit Erkek ve Bayan Güreşçiler İle Spor Yapmayan Bireylerin Liderlik ve Saldırganlık Düzeylerinin İncelenmesi. Uluslararası Egzersiz Psikolojisi Dergisi, 1(1), 33-37

Tutkun, E., Güner, B. Ç., Ağaoğlu, S. A., \& Soslu, R. (2010). Takım Sporları Ve Bireysel Sporlar Yapan Sporcuların Saldırganlık Düzeylerinin Değerlendirilmesi. Spor ve Performans Araştırmaları Dergisi, 1(1), 23-29.

Topuz R. (2008). Amatör Futbol Oyuncularının Saldırganlık Düzeylerinin İncelenmesi, Selçuk Üniversitesi Sağlık Bilimleri Enstitüsü Yüksek Lisans Tezi, Konya

Türkay, İ.K.\& Gökbel, S. (2020). 11-13 Yaş Tenisçilerde Uygulanan Kombine Antrenmanların Vücut Kompozisyonlarına Etkisi, Spor Eğitim Dergisi, 4(1), 33-41

Wittig A. FE. (1984) Sport competition anxiety and sex role. Journal of Sport Psychology, 469473.

Yamak, B., İmamoğlu, O., Eliöz, M., Mehmet, Ç. E. B. İ., \& İslamoğlu, İ. (2019). Spor Lisesi ve Spor Bilimleri Fakültesi Öğrencilerinin Öfke ve Saldırganlık Düzeylerinin Araştırılması. OPUS Uluslararası Toplum Araştırmaları Dergisi, 14(20), 314-332.

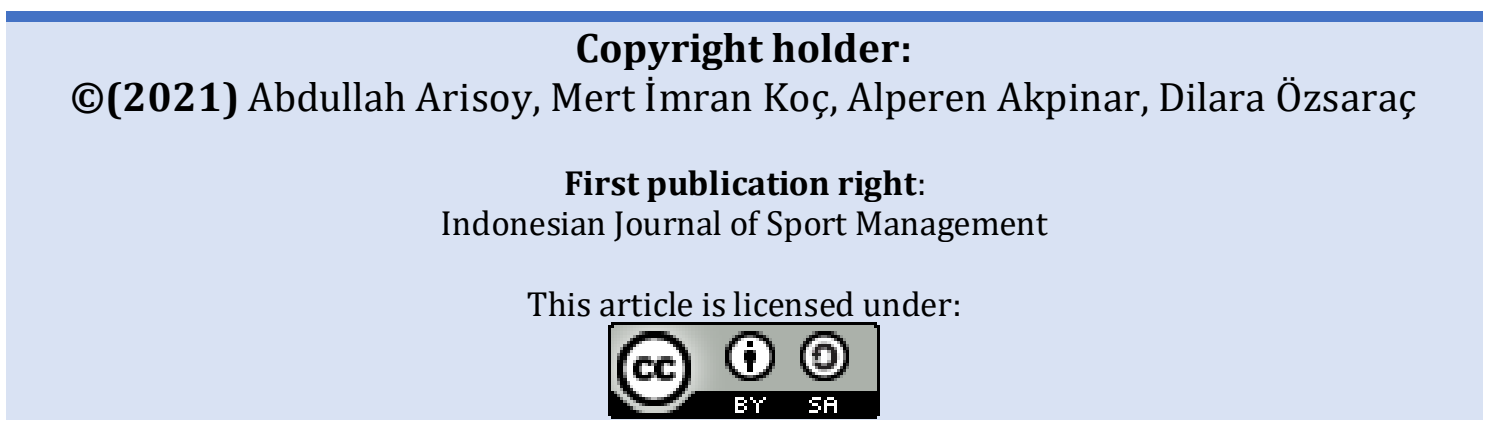

